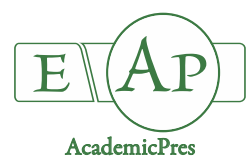

\title{
Nutritional Value of Garden Dill (Anethum graveolens L.), Depending on Genotype
}

\author{
Anita BIESIADA ${ }^{1}$, Kamil KĘDRA ${ }^{1}$, Katarzyna GODLEWSKA ${ }^{1 *}$, \\ Antoni SZUMNY2, Agnieszka NAWIRSKA-OLSZAŃSKA ${ }^{3}$ \\ ${ }^{1}$ Wroclaw University of Environmental and Life Sciences, Faculty of Life Sciences and Technology, Department of Horticulture, Wroclaw, \\ Poland; anita.biesiada@upwr.edu.pl,kamil.kedra@up.wroc.pl,katarzyna.godlewska@upwr.edu.pl (*correspondingauthor) \\ ${ }^{2}$ Wroclaw University of Environmental and Life Sciences, Faculty of Biotechnology and Food Science, Department of Chemistry, Wroctaw, \\ Poland; antoni.szumny@upwr.edu.pl \\ ${ }^{3}$ Wroclaw University of Environmental and Life Science, Faculty of Biotechnology and Food Science, Department of Fruit, Vegetable and Plant \\ Nutraceutical Technology,Wroclaw, Poland; agnieszka.nawirska-olszanska@upwr.edu.pl
}

\begin{abstract}
The yield, chemical composition and antioxidant activity of eight genotypes ('Krezus', 'Turkus', 'Kozak', 'Szmaragd', 'Lukullus', 'Herkules', 'Ambrozja', 'Moravan') of garden dill (Anethum graveolens L.) biomass was estimated. Field experiments were conducted in 2011-2013 in Poland. The crop lasted 44 days and plants were collected at the 4-5 true leaf stage (a bunch harvest). The highest marketable yield was obtained for 'Krezus' and 'Szmaragd' cultivars $\left(1.18 \mathrm{~kg} \cdot \mathrm{m}^{-2}\right)$, while the lowest for 'Herkules' $\left(0.53 \mathrm{~kg} \cdot \mathrm{m}^{-2}\right)$. The dry matter of leaves ranged from $15.17 \%$ ('Ambrozja') to $19.27 \%$ ('Krezus'). The study also proved that the genotype influenced the content of chlorophylls $a+b$, e.g. $1.10 \mathrm{~g} \cdot \mathrm{kg}^{-1}$ ('Moravan') and $0.78 \mathrm{~g} \cdot \mathrm{kg}^{-1}$ ('Lukullus'), respectively carotenoids: $21.43 \mathrm{mg} \cdot 100 \mathrm{~g}^{-1}$ ('Moravan') and $11.78 \mathrm{mg} \cdot 100 \mathrm{~g}^{-1}$ ('Szmaragd'). The content of nitrates (371.48 mg.kg-1 'Lukullus' - 110 mg.kg-1 'Szmaragd'), K (11.30\% 'Moravan' - 5.37\% 'Kozak'), Ca (2.06\% 'Turkus' - 1.77\% 'Kozak'), and oils (99.13\% 'Lukullus' - 93.82\% 'Ambrozja') was also varied. In most cases the content of Mg, P, sugars and ascorbic acid was on similar level. The antioxidant activity was significantly different between tested groups $\left(12.22 \mu \mathrm{M} \cdot \mathrm{g}^{-1}\right.$ 'Turkus' $-6.27 \mu \mathrm{M} \cdot \mathrm{g}^{-1}$ 'Krezus'). The presented research proved that the genotype of garden dill affects yield and chemical composition of plants.
\end{abstract}

Keywords: antioxidant activity; chemical composition; garden dill; genotype; yield

\section{Introduction}

The secondary metabolites, produced by all plants, act as repellents to herbivores or as biocides against microbial pathogens. The content of a metabolite in medicinal plants is economically more important than the yield of the desirable part, because it determines the cost of extraction. Such plants play a significant role in human health protection and currently many people are turning to herbal medicine (Weisany et al., 2015). Nowadays, the use of natural products in the pharmaceutical and food industries is gaining importance. The manufacturers search for natural compounds that preserve food and promote the perception of flavours and aromas (Garcez et al., 2017). An extensive body of research has demonstrated that dill (Anethum graveolens L.) contains unique and valuable components such as: essential oils, proteins, fibre, fatty oil, carbohydrates and macroelements (e.g. Ca, K, Mg, P, Na), vitamin A and niacin (Ghassemi-Golezani et al., 2011). Due to its combined properties, is widely used in traditional medicine, in the culinary, cosmetic and nutraceutical industries (Zheljazkov et al., 2006). Extract of seeds exhibits antioxidant, anti-inflammatory, antifungal and antimicrobial activities that favor the preservation of food and protection against food pathogens (Garcez et al., 2017). Dill also is used in treatment of most gastrointestinal problems, as a cholesterol-lowering and diuretic agent, and has lactagogue, anticonvulsion, antiemetic, antispasmodic and antidiabetic properties. The hebral extracts and oils are gaining popularity because they are commonly cultivated and safe for people (El-Zaeddi et al., 2016), compared to the chemical preservatives used by large scale manufactures. Considering that dill is usually applied as a herb, its cultivation does not focus on maximum seed yield (Zheljazkov et al., 2006). The yield, taste and quality depend 
on many factors, e.g. cultivar, climatic and soil condition, fertilization, seeding date, harvest date, weed competition, plant disease, management practices, stage of growth, geographical variation, water stress, wind of higher velocity, storage, and processing conditions (Bowes et al., 2004; ElZaeddi et al., 2016; El-Zaeddi et al., 2017). It was also observed that plants grown at low density had lower proportion of steam and leaf tissue and more extensive development of umbellate fruiting structures compared to plants grown at high density (El-Zaeddi et al., 2017).

Due to the wide range of chemical composition and many pharmacological effects, there is a great promise for use of dill in development of novel drugs to treat human diseases as a result of its effectiveness and safety. For this reason, it is very important to increase knowledge concerning the detailed composition of garden dill depending on genotype, especially that currently available literature data are scarce. Dill is also undoubtedly the most widely used herbal spice in Poland and even outstrips parsley. This spring vegetable, harvested for bunches, is the principal flavor accent in Polish cuisine.

The aim of the present study was to determine the potential to grow dill as an essential oil crop in Poland and to observe the effect of genotype on yield, chemical composition and antioxidant activity. To meet these objectives field experiments and laboratory analyses were carried out in 2011 and 2013.

\section{Materials and Methods}

All the reagents used in the experiment were of analytical grade. 1,1-diphenyl-2 picrylhydrazyl (DPPH); 6ydroxy-2,5,7,8-tetramethylchroman- 2-carboxylic acid (Trolox) were obtained from Sigma (Germany). To determine dry matter five samples of leaves from each plot of treatment were randomly selected at harvest, then dried to constant weight at $105^{\circ} \mathrm{C}$ (dryer BINDER FD 240) and ground in a MF 10 Basic mill (IKA-Werke, GmbH \& Co. KG, Staufen, Germany) to mesh size $<0.25 \mathrm{~mm}$. In each treatment four replicates were used. The content of chlorophyll $a+b$ and carotenoids was analysed using colorimetric methods (Rumińska, Suchorska, Węglarz, 1990). The nitrates were marked potentiometrically in $2 \%$ acetic acid extract (Nowosielski, 1988). The contents of $\mathrm{Mg}$ and $\mathrm{P}$ were analysed using colorimetric method, while the amounts of $\mathrm{Ca}$ and $\mathrm{K}$ by using the flame photometry method (Nowosielski, 1988). Colorimetric measurements were made using a Perkin Elmer Model Lambda 1A spectrophotometer (Perkin Elmer, Waltham, MA, USA.) and the flame emission spectroscopy with a Sherwood, Model 410, Cambridge, UK. The volatile fractions were prepared in a Dering apparatus by simultaneous distillationextraction (SDE) in $1 \mathrm{ml}$ hexane or in diisopropyl ether for $12 \mathrm{~h}$. The oil was analyzed using a Saturn GC/MS/MS 2000 apparatus. The operating parameters were as follows: carrier gas - helium, at flow rate $2 \mathrm{ml} / \mathrm{min}$, column Chrompack capillary CP-sil 5 (CB, $25 \mathrm{~m} \times 0.25 \mu \mathrm{m} \times 0.25$ $\mathrm{mm})$, temperature $50{ }^{\circ} \mathrm{C}$ - for $5 \mathrm{~min}$, next $50-200$ at $3{ }^{\circ} \mathrm{C}$ $\mathrm{min}^{-1}$, finally $300^{\circ} \mathrm{C}-10 \mathrm{~min}$. Volume injected: $5 \mu \mathrm{L}$, split ratio 1:50. The MS parameters were as follows: ionization potential $70 \mathrm{eV}$, ionization current $2 \mathrm{~A}$, ion source temperature $200{ }^{\circ} \mathrm{C}$. Identification of components in oil was based on computer matching with the NIST Spectral Library (NIST 05), Standard Saturn Mass Spectral Libraries and retention index. Commercial samples of some terpenes were used as standards. The sugars were assayed with the Lane-Eynon method in frozen biomass. To determine the content of L-ascorbic acid the Tillmans method was used (PN-A-04019, 1998). The antioxidant activity was examined using the DPPH radical-scavenging method (Yen and Chen, 1995). Field experiments were conducted in $2011-2013$ in Research Station at Psary $\left(51^{\circ} 11^{\prime} 25.27^{\prime \prime} \mathrm{N}\right.$ $\left.17^{\circ} 2^{\prime} 3.08^{\prime \prime} \mathrm{E}\right)$, belonging to the Department of Horticulture of Wrocław University of Environmental and Life Sciences. The fine clay soil ( $\mathrm{pH} 7.6$ ), containing 1.8\% humus, $60 \mathrm{mg}$ $\mathrm{P}, 180 \mathrm{mg} \mathrm{K}$ and $60 \mathrm{mg} \mathrm{Mg}$ in $1 \mathrm{dm}^{3}$, was fertilized with ammonium nitrate $\left(100 \mathrm{~kg} \mathrm{~N} \mathrm{ha}^{-1}\right)$, potassium sulphate $\left(195 \mathrm{~kg} \mathrm{~K} \mathrm{ha}^{-1}\right)$ and magnesium sulfate $\left(450 \mathrm{~kg} \mathrm{ha}^{-1}\right)$ before sowing. Dill seeds of 8 genotypes: 'Krezus', 'Turkus', 'Kozak', 'Szmaragd', 'Lukullus', 'Herkules', 'Ambrozja' and 'Moravan' were soaked with Grevit 200 SL (0.5\%) and then sown on $5^{\text {th }}$ April at the amount of $20 \mathrm{~kg} \mathrm{ha}^{-1}$ onto plots of 1 $\mathrm{m}^{2}$ area, in $20 \mathrm{~cm}$ spacing, at the depth of $2 \mathrm{~cm}$. During plant growth the typical cultivation treatments (e.g. regular mechanical weeding, irrigation, plants protection against aphids) were applied. Plants were irrigated every 4 days with a dose $15 \mathrm{~mm} \mathrm{~m}^{-2}$. The crop lasted 44 days and plants were collected on $14^{\text {th }}$ May at the 4-5 true leaf stage (a bunch harvest). The average air temperatures and precipitation in April were: for $2011: 13.83^{\circ} \mathrm{C}$ and $4.20 \mathrm{~mm}$; for 2012 : $10.83{ }^{\circ} \mathrm{C}$ and $26.40 \mathrm{~mm}$; for $2013: 13.17^{\circ} \mathrm{C}$ and $24.0 \mathrm{~mm}$. In May were: for 2011: $15.83^{\circ} \mathrm{C}$ and $54.20 \mathrm{~mm}$; for 2012: 13.20 ${ }^{\circ} \mathrm{C}$ and $134.50 \mathrm{~mm}$; for 2013 : $14.78^{\circ} \mathrm{C}$ and 41.40 $\mathrm{mm}$. The data obtained were subjected to statistical analysis.

\section{Results and Discussion}

\section{Yield}

In Table 1, the productivity of different cultivars of dill, cultivated for bunches, are presented. The differences were statistically significant $(\alpha=0.05)$. Results showed that $\mathrm{cv}$. 'Krezus' and 'Szmaragd' have the highest average fresh mass $\left(1.18 \mathrm{~kg} \mathrm{~m}^{-2}\right)$ while the lowest was observed for 'Herkules' $\left(0.53 \mathrm{~kg} \mathrm{~m}^{-2}\right)$. Literature data regarding the productivity of garden dill are divergent. Karkleliene et al. (2014) presented productivity of dill harvested after 50-60 days of growing. The highest yields were for cv. 'Common' (29.1 t ha ${ }^{-1}$ ) and 'Szmaragd' while the lowest for 'Moravan'. Kawecka and Dyduch (2006) investigated the effect of cultivar, sowing date and year on productivity of dill under Polish climatic conditions. The research proved that these factors have a significant impact on the plant yield. The plants were cropped when the majority of them were $20-25 \mathrm{~cm}$ high. The biggest biomass was recorded for 'Ambrozja' (21.39 $\mathrm{t}$ $\left.\mathrm{ha}^{-1}\right)$. The varieties 'Amat' (19.66 t ha $\mathrm{ha}^{-1}$ ) and 'Fantazos' $\left(19.10 \mathrm{t} \mathrm{ha}^{-1}\right)$ were also sufficiently high. The lowest yield was obtained for 'Kronos' $\left(16.48 \mathrm{t} \mathrm{ha}^{-1}\right)$. The productivity of 'Szmaragd' amounted to $18.16 \mathrm{t} \mathrm{ha}^{-1}$. The best sowing date proved to be month June (25.25 $\left.\mathrm{t} \mathrm{ha}^{-1}\right)$ and year 2003 (21 t $\left.\mathrm{ha}^{-1}\right)$. Those studies confirmed that the yield of garden dill depends on many factors (e.g. term of seed sowing, harvest stage, climatic and soil condition) and emphasized the need for more controlled experiments to back up the clear-cut conclusions. 
786

Table 1 . The yield $\left(\mathrm{kg} \cdot \mathrm{m}^{-2}\right)$ of different cultivars of dill

\begin{tabular}{|c|c|c|c|c|}
\hline Cultivar & 2011 & 2012 & 2013 & Mean \\
\hline 'Krezus' & $1.12 \mathrm{a}$ & $1.07 \mathrm{~b}$ & $1.35 \mathrm{a}$ & $1.18 \mathrm{a}$ \\
\hline 'Turkus' & $0.86 \mathrm{c}$ & $0.75 f$ & $0.87 \mathrm{c}$ & $0.83 \mathrm{~cd}$ \\
\hline 'Kozak' & $0.77 \mathrm{e}$ & $0.72 \mathrm{f}$ & $0.80 \mathrm{~d}$ & $0.76 \mathrm{ef}$ \\
\hline 'Szmaragd' & $1.00 \mathrm{~b}$ & $1.20 \mathrm{a}$ & $1.35 \mathrm{a}$ & $1.18 \mathrm{a}$ \\
\hline 'Lukullus' & $0.99 \mathrm{~b}$ & $0.92 \mathrm{c}$ & $0.98 b$ & $0.96 \mathrm{~b}$ \\
\hline 'Herkules' & $0.56 f$ & $0.51 \mathrm{~g}$ & $0.53 \mathrm{f}$ & $0.53 \mathrm{~g}$ \\
\hline 'Ambrozja' & $0.87 \mathrm{c}$ & $0.85 \mathrm{~d}$ & $0.82 \mathrm{~d}$ & $0.85 c$ \\
\hline 'Moravan' & $0.80 \mathrm{~d}$ & $0.81 \mathrm{e}$ & $0.73 \mathrm{e}$ & $0.78 \mathrm{e}$ \\
\hline
\end{tabular}

a, b, c... - statistically not significant differences between examined groups each year

\section{Drymatter}

Dry matter (d.m.) was found to range from 15.17 to $19.27 \%$ (Table 2). According to USDA Food Composition Database, fresh dill weed contains $85.95 \mathrm{~g}$ of water per $100 \mathrm{~g}$ (14.05\% d.m.). The genotypes tested in our experiments were characterized by higher content of dry matter. The lowest value was measured for 'Ambrozja' and the highest for 'Krezus'. It can be noted that in the year 2011 plants were characterized by highest content of dry matter while lowest, in most cases, was in 2013. Karkleliene et al. (2014) stated that d.m. contents in dill amount to $12.2,13.3,14.0$ and $14.7 \%$ for 'Common', 'Moravan', 'Mammoth' and 'Szmaragd', respectively. Comparing these results, it can be seen that in our experiment cv. 'Moravan' and 'Szmaragd' were higher in weight by 41 and $20 \%$, respectively.

\section{Chlorophylls $a, b$ and $a+b$ content}

Photosynthesis is the one of the most important processes that enables plant to grow by utilizing water, carbon dioxide and minerals. To convert the light energy into chemical energy the chlorophyll is necessary. It catalyzes the primary photochemical process which is an energy-storing chemical reaction (Huang et al., 2017).

The concentrations of chlorophyll $a, b$ and $a+b$ in cultivated garden dill are presented in Table 3 . The highest amount of chlorophyll $a$, chlorophyll $b$ and chlorophyll $a+b$ were found in 'Moravan' $\left(0.79 \mathrm{~g} \mathrm{~kg}^{-1}\right.$ f.m., $0.31 \mathrm{~g} \mathrm{~kg}^{-1}$ f.m., $1.10 \mathrm{~g} \mathrm{~kg}^{-1}$ f.m., respectively) and 'Szmaragd' ( $0.74 \mathrm{~g} \mathrm{~kg}^{-1}$ f.m., $0.25 \mathrm{~g} \mathrm{~kg}^{-1}$ f.m., $0.99 \mathrm{~g} \mathrm{~kg}^{-1}$ f.m., respectively). The lowest concentration of chlorophyll $a\left(0.56 \mathrm{~g} \mathrm{~kg}^{-1}\right.$ f.m.) and chlorophyll $a+b\left(0.78 \mathrm{~g} \mathrm{~kg}^{-1}\right.$ f.m.) was observed in 'Lukullus', while chlorophyll $b\left(0.18 \mathrm{~g} \mathrm{~kg}^{-1}\right.$ f.m. $)$ in 'Herkules'. In the work of Karkleliene et al. (2014) the highest content of chlorophylls was measured for cv. 'Moravan' (2.04 $\mathrm{mg} \mathrm{g}^{-1}$ ) and 'Common' (2.02 $\left.\mathrm{mg} \mathrm{g}^{-1}\right)$. The lowest quantity was recorded in 'Szmaragd'.

Table 2. The dry matter (\%) of different cultivars of dill $(\mathrm{N}=4)$

\begin{tabular}{ccccc}
\hline Cultivar & 2011 & 2012 & 2013 & Mean \\
\hline 'Krezus' & $19.72 \mathrm{a}$ & $19.38 \mathrm{a}$ & $18.71 \mathrm{a}$ & $19.27 \mathrm{a}$ \\
'Turkus' & $18.06 \mathrm{bd}$ & $17.29 \mathrm{ce}$ & $17.47 \mathrm{ef}$ \\
'Kozak' & $18.41 \mathrm{bcd}$ & $18.36 \mathrm{~b}$ & $18.40 \mathrm{ab}$ & $17.34 \mathrm{~d}$ \\
'Szmaragd' & $17.62 \mathrm{f}$ & $17.59 \mathrm{~cd}$ & $16.31 \mathrm{f}$ & $17.51 \mathrm{e}$ \\
'Lukullus' & $17.66 \mathrm{e}$ & $16.63 \mathrm{f}$ & $18.60 \mathrm{a}$ & $16.87 \mathrm{~g}$ \\
'Herkules' & $18.47 \mathrm{bc}$ & $18.48 \mathrm{~b}$ & $15.36 \mathrm{~g}$ & $17.96 \mathrm{c}$ \\
\hline 'Ambrozja' & $15.30 \mathrm{~g}$ & $14.86 \mathrm{~g}$ & $15.17 \mathrm{~h}$ \\
\hline
\end{tabular}

a, b, c... - statistically not significant differences between examined groups each year

Table 3. Chlorophyll $a$ (g. $\mathrm{kg}^{-1} \mathrm{f} . \mathrm{m}$.), chlorophyll $b$ (g. $\left.\mathrm{kg}^{-1} \mathrm{f} . \mathrm{m}.\right)$, chlorophyll $a+b$ (g.kg $\mathrm{kg}^{-1} \mathrm{f} . \mathrm{m}$.), carotenoids (mg.100g $\mathrm{g}^{-1}$ f.m.) content in different cultivars of dill (mean for 2011-2013) ( $\mathrm{N}=4)$

\begin{tabular}{|c|c|c|c|c|c|c|c|c|c|}
\hline & Year/Cultivar & 'Krezus' & 'Turkus' & 'Kozak' & 'Szmaragd' & 'Lukullus' & 'Herkules' & 'Ambrozja' & 'Moravan' \\
\hline \multirow{4}{*}{ Chlorophyll $a$} & 2011 & $0.70 b c$ & $0.71 \mathrm{c}$ & $0.68 \mathrm{~cd}$ & $0.72 b$ & $0.54 \mathrm{e}$ & $0.74 \mathrm{ab}$ & $0.73 b$ & $0.79 a$ \\
\hline & 2012 & $0.67 \mathrm{~cd}$ & $0.67 \mathrm{~cd}$ & $0.65 \mathrm{cde}$ & $0.73 b$ & $0.54 \mathrm{f}$ & $0.66 \mathrm{cde}$ & $0.68 c$ & $0.77 \mathrm{a}$ \\
\hline & 2013 & $0.72 \mathrm{~cd}$ & $0.72 \mathrm{~cd}$ & $0.70 \mathrm{de}$ & $0.78 b$ & $0.59 \mathrm{f}$ & $0.71 \mathrm{~cd}$ & $0.73 c$ & $0.82 \mathrm{a}$ \\
\hline & Mean & $0.69 \mathrm{~cd}$ & $0.70 \mathrm{~cd}$ & $0.67 \mathrm{de}$ & $0.74 b$ & $0.56 \mathrm{f}$ & $0.70 \mathrm{~cd}$ & $0.71 \mathrm{c}$ & $0.79 \mathrm{a}$ \\
\hline \multirow{4}{*}{ Chlorophyll $b$} & 2011 & $0.19 \mathrm{~cd}$ & $0.19 \mathrm{~d}$ & $0.20 \mathrm{~cd}$ & $0.25 b$ & $0.22 c$ & $0.18 \mathrm{~d}$ & $0.22 c$ & $0.29 a$ \\
\hline & 2012 & $0.20 \mathrm{ce}$ & $0.20 \mathrm{ce}$ & $0.22 \mathrm{bd}$ & $0.25 b$ & $0.23 b c$ & $0.18 \mathrm{ef}$ & $0.23 \mathrm{bc}$ & $0.30 \mathrm{a}$ \\
\hline & 2013 & $0.21 b c$ & $0.20 \mathrm{bd}$ & $0.21 b c$ & $0.24 b$ & $0.23 b$ & $0.19 \mathrm{~cd}$ & $0.22 b c$ & $0.33 a$ \\
\hline & Mean & $0.20 \mathrm{cf}$ & $0.20 \mathrm{cf}$ & $0.21 \mathrm{ce}$ & $0.25 b$ & $0.23 \mathrm{bc}$ & $0.18 \mathrm{fg}$ & $0.22 \mathrm{bd}$ & $0.31 \mathrm{a}$ \\
\hline \multirow{4}{*}{ Chlorophyll $\mathrm{a}+b$} & 2011 & $0.88 \mathrm{def}$ & $0.90 \mathrm{cde}$ & $0.88 \mathrm{def}$ & $0.97 \mathrm{~b}$ & $0.76 \mathrm{~g}$ & $0.92 \mathrm{bcd}$ & $0.95 b c$ & $1.08 \mathrm{a}$ \\
\hline & 2012 & $0.87 \mathrm{~cd}$ & $0.86 \mathrm{de}$ & $0.87 \mathrm{~d}$ & $0.98 b$ & $0.77 \mathrm{~g}$ & $0.84 \mathrm{def}$ & $0.91 \mathrm{c}$ & $1.07 \mathrm{a}$ \\
\hline & 2013 & $0.93 \mathrm{~cd}$ & $0.92 \mathrm{cde}$ & 0.91cde & $1.02 \mathrm{~b}$ & $0.82 \mathrm{~g}$ & $0.90 \mathrm{cdef}$ & $0.95 \mathrm{c}$ & $1.14 \mathrm{a}$ \\
\hline & Mean & $0.89 \mathrm{~cd}$ & $0.89 \mathrm{~cd}$ & $0.88 \mathrm{~d}$ & $0.99 \mathrm{~b}$ & $0.78 \mathrm{e}$ & $0.89 \mathrm{~cd}$ & $0.93 c$ & $1.10 \mathrm{a}$ \\
\hline \multirow{4}{*}{ Carotenoids } & 2011 & $18.25 \mathrm{bcd}$ & $16.10 \mathrm{f}$ & $18.83 \mathrm{~b}$ & $10.65 \mathrm{~g}$ & $18.44 \mathrm{bc}$ & $17.35 \mathrm{de}$ & $21.29 a$ & $21.29 \mathrm{a}$ \\
\hline & 2012 & $18.04 \mathrm{de}$ & $16.31 \mathrm{~g}$ & $18.77 \mathrm{c}$ & $12.18 \mathrm{~h}$ & $18.25 \mathrm{~d}$ & $17.68 \mathrm{ef}$ & $21.70 \mathrm{a}$ & $21.22 \mathrm{ab}$ \\
\hline & 2013 & $17.41 \mathrm{~d}$ & $15.85 \mathrm{f}$ & $18.44 \mathrm{c}$ & $12.52 \mathrm{~g}$ & $17.45 \mathrm{~d}$ & $17.10 \mathrm{de}$ & $20.42 b$ & $21.79 \mathrm{a}$ \\
\hline & Mean & $17.90 \mathrm{de}$ & $16.09 \mathrm{~g}$ & $18.68 \mathrm{c}$ & $11.78 \mathrm{~h}$ & $18.04 \mathrm{~d}$ & $17.37 \mathrm{def}$ & $21.14 \mathrm{ab}$ & $21.43 \mathrm{a}$ \\
\hline
\end{tabular}

a, b, c... - statistically not significant differences between examined groups each year 


\section{Carotenoids}

Carotenoids should be constituents of a healthy diet due to their antioxidant and immune system activity (Gammone et al., 2015). The main sources of carotenoids are fruits and vegetables. For instance carotenes are involved in skin protection and the xanthophylls in eye preservation (Gammone et al., 2015). Due to the fact that carotenoids are not synthesized by the human body they have to be obtained from dietary sources (Berman et al., 2015). The proper intake of carotenoids in the human diet can reduce the occurrence of disease such as cancer, cardiovascular diseases, cataract formation and age related macular degradation. The deficiency of these compounds can result in clinical signs of conjunctiva, vision disability and increased mortality caused by weakened immunity (Saini $e t$ al., 2015).

It was found that the highest quantity of carotenoids (Table 3) exhibits the 'Moravan' (21.43 mg $\left.100 \mathrm{~g}^{-1} \mathrm{f} . \mathrm{m}.\right)$ and 'Ambrozja' (21.14 mg $100 \mathrm{~g}^{-1}$ f.m.), and the lowest in the 'Szmaragd' cv. (11.78 mg $100 \mathrm{~g}^{-1}$ f.m.). In the work by Karkleliene et al. (2014) also 'Moravan' was characterized by highest content of this pigment (10.3 mg $\left.100 \mathrm{~g}^{-1}\right)$ and 'Szmaragd' contained $9.7 \mathrm{mg} 100 \mathrm{~g}^{-1}$.

\section{$\mathrm{NO}_{3}$ content}

Nitrates occur naturally in food, drinking water and vegetables. The acceptable daily intake of 0-3.7 per $\mathrm{mg} \mathrm{kg}^{-1}$ body weight for nitrates has been established by the EU Scientific Committee for Food (Tamme et al., 2006). It is worth mentioning that nitrates $(\mathrm{V})$ are low toxic and do not constitute a direct threat to human health, and deadly poisoning are rare (Telesiński et al., 2013).

In the present investigation was found (Table 4) that genotype significantly influenced the nitrates content in seedlings of dill that ranged from 110.75 to $371.90 \mathrm{mg}$ in 1 $\mathrm{kg}$ of fresh matter for 'Szmaragd' and 'Lukullus', respectively. Higher levels of nitrates, above $200 \mathrm{mg} \mathrm{kg}^{-1}$, have also been reported for 'Turkus' (296.55 $\mathrm{mg} \mathrm{kg}^{-1}$ f.m.) and 'Herkules' (247.49 $\mathrm{mg} \mathrm{kg}^{-1}$ f.m.). In order to protect the consumer's health from food contaminated with nitrates, the Polish legislation introduced standards for permitted levels of the compounds in vegetables. According to Commission Regulation (2006) - EC No 1881/2006 of 19 December 2006 the permissible level of nitrate pollution in leaf vegetables is e.g.: fresh spinach (Spinacia oleracea) (2500-3000 mg NO $\mathrm{mg}_{3}^{-1}$ ) and lettuce grown in ground (2500-4000 mg NO $\left.\mathrm{mg}^{-1}\right)$. For herbs and spice plants such standards are not given (Dec et al., 2008). Comparing research results with the acceptable standard of these compounds in leafy vegetables, it can be stated that the content was relatively small (below $200 \mathrm{mg} \mathrm{kg}^{-1}$ f.m.) and could be successfully used in the production of e.g. baby food. In addition, it should be noted that daily consumption of spice herbs is not high, therefore the daily intake of nitrate with these raw materials is small.

\section{Macroelements}

During the past few decades, extensive study on nutrient elements has been carried out to define their role in the plant. Interactions between these chemical substances are one of the main causes of deficiency and toxicity symptoms in higher plants. It occurs when the supply of one nutrient influences the uptake, transport, utilization and function of another nutrient within a wide range of plant tissues (Farzadfar et al., 2017).

Table 5 presents content of $\mathrm{K}, \mathrm{Mg}, \mathrm{P}$ and $\mathrm{Ca}$ in different cultivars of dill. 'Moravan' was especially rich in K (11.30\% d.m.) and the poorest was 'Kozak' (5.37\%). According to USDA Food Composition Database dried dill contains $3.3 \%$ of $\mathrm{K}$, which is significantly lower in comparison to our tested cultivars. Magnesium and phosphorus in all tested dill genotype was at similar level and was significantly lower compared to the USDA database (0.45 and 54\%, respectively). We have found that the lowest $\mathrm{Ca}$ content was in cv. 'Kozak' (1.77\%) and the highest in 'Turkus' $(2.06 \%)$. In most cases the content of $\mathrm{Ca}$ was higher in testest varieties than in data presented in USDA (1.78\%).

\section{Essential oil constituents}

One of the most important groups among secondary metabolites in dill are essential oils. Dill contains two types of essential oils which differ in their chemical composition and perform different functions. The first type could be

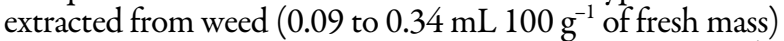
and the second from mature seeds $\left(0.2\right.$ and $\left.4.6 \mathrm{~mL} 100 \mathrm{~g}^{-1}\right)$. The essential fruit oil consists mainly of limonene and carvone, whereas weed oil includes $\alpha$-phellandrene, myristicin and apiole (Bowes et al., 2004). It is well-known that the specific aroma of plant is determined by the concentration and composition of essential oils (El-Zaeddi et al., 2016) and is formed by complex of chemical substances, such as: alcohols, ketones, aldehydes, esters, terpenes and lactones (El-Zaeddi et al., 2017). An important component identified in dill is dill ether, which due to its high odoractivity value, is considered as the character impact compound of its flavour. Smell reminiscent 'citruslike' and 'pine-like' odors are assign to limonene and $\alpha$ pinene, respectively (Callan et al., 2007).

Table $4 . \mathrm{NO}_{3}$ content $\left(\mathrm{mg} \cdot \mathrm{kg}^{-1} \mathrm{f}\right.$.m. $)$ in different cultivars of dill

\begin{tabular}{|c|c|c|c|c|}
\hline Cultivar & 2011 & 2012 & 2013 & Mean \\
\hline 'Krezus' & $150.36 \mathrm{e}$ & $152.69 \mathrm{e}$ & $144.56 \mathrm{e}$ & $149.20 \mathrm{e}$ \\
\hline 'Turkus' & $295.17 b$ & $296.35 b$ & $298.14 b$ & $296.55 b$ \\
\hline 'Kozak' & $181.36 \mathrm{~d}$ & $182.35 \mathrm{~d}$ & $186.25 \mathrm{~d}$ & $183.32 \mathrm{~d}$ \\
\hline 'Szmaragd' & $105.12 \mathrm{~g}$ & $112.54 \mathrm{~g}$ & $114.58 \mathrm{gh}$ & $110.75 \mathrm{gh}$ \\
\hline 'Lukullus' & $372.21 \mathrm{a}$ & $370.25 a$ & $373.25 a$ & $371.90 \mathrm{a}$ \\
\hline 'Herkules' & $269.47 \mathrm{c}$ & $252.45 c$ & $258.25 c$ & $247.49 c$ \\
\hline 'Ambrozja' & $105.64 \mathrm{~g}$ & $120.23 \mathrm{fg}$ & $124.23 \mathrm{fg}$ & $116.70 \mathrm{fg}$ \\
\hline 'Moravan' & $136.45 \mathrm{f}$ & $123.69 \mathrm{f}$ & $126.25 f$ & $128.80 \mathrm{f}$ \\
\hline
\end{tabular}


788

Another important odorants showing high OAV are: $\alpha$ phellandrene, myristicin and limonene. Apiole and myristicin, present in low quantities, could be typical for some varieties and lead to distinction of chemotypes. Due to the relatively soft dill peel the oil might be easily accessible. The essential oils have unique composition and are widely used in the food, cosmetic, pharmaceutical, perfumery and nutraceuticals industries (Zheljazkov et al., 2006), e.g. nearly pure D-limonene present in seed oil exhibits antimicrobial activity (Bowes et al., 2004). Literature data concerning the essential oil content of different genotypes of dill are scarce.

The mean content of oils in leaves is presented in Table 6. It can be seen that dill leaves contain $\alpha$-phellandrene (50.78-64.55\%), dill ether (14.87-24.81\%), $\beta$-phellandrene (5.34-7.57\%), apiol (1.05-6.92\%), limonene (2.37-2.66\%), p-cymene (1.33-2.29\%), and a-pinene (1.24-1.72\%) as main compounds. The highest total mean content of essential oils was noted for 'Lukullus' $(99.13 \pm 0.81)$ and the lowest for 'Ambrozja' (93.82 \pm 0.80$)$. The oil composition was found to be similar as reported in other studies, however differences were observed in their quantities. Hajhashemi et al. (2008) found that the aerial parts contain $\alpha$-phellandrene (32\%), limonene (28\%) and carvone $(28 \%)$ in greatest amounts. Whereas Rana et al. (2014) showed that the main compounds were $\alpha$-phellandrene (31.8\%), apiole (15.3\%), dill ether (13.2\%), limonene (11.8\%), geraniol (10.6\%) and p-cymene (5.3\%). In the work by Jianu et al. (2012) dill stems contain: terpinene (31.66\%), phellandrene (24.94\%), limonene (12.95\%), and p-cymene (12.59\%). Rădulescu et al. (2010) reported that the oil composition depends on the dill parts. The highest area $\%$ of essential oils was in fruits and flowers (99.97 and 99.83\%, respectively) and lowest in leaves $(97.55 \%)$. The predominant oil in fruits was carvone (75.21\%), while in flowers and leaves it was $\alpha$-phelandrene (32.26, 62.71\%, respectively) and limonene (33.22\%, $13.28 \%$, respectively). According to Olle et al. (2010) dill fruits contain $2.5-4 \%$ of essential oils (mainly carvone (40$55 \%)$ ), while leaves contains $0.05-0.35 \%$ (mostly phellandrene, 46\%). The differences in the amounts of individual oils result from e.g. climatic condition, fertilization or age of plant, and in the scientific data have not been sufficiently described.

Table 5. Macroelements content (\% d.m.) in different cultivars of dill

\begin{tabular}{|c|c|c|c|c|c|c|c|c|c|}
\hline & Cultivar & 'Krezus' & 'Turkus' & 'Kozak' & 'Szmaragd' & 'Lukullus' & 'Herkules' & 'Ambrozja' & 'Moravan' \\
\hline \multirow{4}{*}{ K } & 2011 & $5.34 \mathrm{~g}$ & $9.31 \mathrm{~b}$ & $5.23 \mathrm{~g}$ & $8.74 \mathrm{c}$ & $6.44 \mathrm{f}$ & $6.94 \mathrm{e}$ & $7.14 \mathrm{~d}$ & $10.34 a$ \\
\hline & 2012 & $6.34 \mathrm{f}$ & $9.71 \mathrm{~b}$ & $5.24 \mathrm{~g}$ & $8.45 c$ & $6.53 \mathrm{f}$ & $6.84 \mathrm{e}$ & $7.22 \mathrm{~d}$ & $12.07 \mathrm{a}$ \\
\hline & 2013 & $6.62 \mathrm{efg}$ & $9.09 \mathrm{~b}$ & $5.65 \mathrm{~h}$ & $8.74 b c$ & $6.85 \mathrm{ef}$ & $6.88 \mathrm{e}$ & $7.61 \mathrm{~d}$ & $11.49 \mathrm{a}$ \\
\hline & 2011-2013 & $6.10 \mathrm{~g}$ & $9.37 \mathrm{~b}$ & $5.37 \mathrm{~h}$ & $8.64 \mathrm{c}$ & $6.61 \mathrm{f}$ & $6.88 \mathrm{e}$ & $7.32 \mathrm{~d}$ & $11.30 \mathrm{a}$ \\
\hline \multirow{4}{*}{$\mathrm{Mg}$} & 2011 & $0.34 \mathrm{ab}$ & $0.32 \mathrm{ab}$ & $0.34 a$ & $0.30 \mathrm{ab}$ & $0.31 \mathrm{ab}$ & $0.33 \mathrm{ab}$ & $0.33 \mathrm{ab}$ & $0.33 \mathrm{ab}$ \\
\hline & 2012 & $0.33 \mathrm{ab}$ & $0.32 \mathrm{abc}$ & $0.34 \mathrm{a}$ & $0.30 b c$ & $0.32 \mathrm{abc}$ & $0.32 \mathrm{abc}$ & $0.32 \mathrm{abc}$ & $0.32 \mathrm{abc}$ \\
\hline & 2013 & $0.31 \mathrm{abc}$ & $0.32 \mathrm{abc}$ & $0.33 \mathrm{ab}$ & $0.32 \mathrm{abc}$ & $0.34 \mathrm{a}$ & $0.32 \mathrm{abc}$ & $0.33 \mathrm{ab}$ & $0.34 a$ \\
\hline & 2011-2013 & $0.32 \mathrm{ab}$ & $0.32 \mathrm{ab}$ & $0.33 a$ & $0.31 \mathrm{~b}$ & $0.32 \mathrm{ab}$ & $0.32 \mathrm{ab}$ & $0.33 \mathrm{a}$ & $0.33 a$ \\
\hline \multirow{4}{*}{$\mathrm{P}$} & 2011 & $0.29 \mathrm{ab}$ & $0.30 \mathrm{a}$ & $0.19 \mathrm{~d}$ & $0.25 \mathrm{abc}$ & $0.27 \mathrm{ab}$ & $0.28 \mathrm{ab}$ & $0.28 \mathrm{ab}$ & $0.26 \mathrm{abc}$ \\
\hline & 2012 & $0.31 \mathrm{a}$ & $0.30 \mathrm{a}$ & $0.23 \mathrm{bcd}$ & $0.25 \mathrm{ab}$ & $0.28 \mathrm{a}$ & $0.25 \mathrm{ab}$ & $0.24 a b c$ & $0.23 \mathrm{bcd}$ \\
\hline & 2013 & $0.26 \mathrm{a}$ & $0.27 \mathrm{a}$ & $0.24 \mathrm{ab}$ & $0.25 \mathrm{ab}$ & $0.24 a b$ & $0.28 \mathrm{a}$ & $0.26 a$ & $0.25 \mathrm{ab}$ \\
\hline & 2011-2013 & $0.29 a$ & $0.29 \mathrm{a}$ & $0.22 \mathrm{abc}$ & $0.25 \mathrm{ab}$ & $0.26 \mathrm{a}$ & $0.27 \mathrm{a}$ & $0.26 a$ & $0.24 a b$ \\
\hline \multirow{4}{*}{$\mathrm{Ca}$} & 2011 & $1.93 \mathrm{ab}$ & $1.98 \mathrm{a}$ & $1.75 \mathrm{abc}$ & $1.83 \mathrm{abc}$ & $1.92 \mathrm{abc}$ & $2.06 \mathrm{ab}$ & $2.06 \mathrm{a}$ & $2.02 \mathrm{ab}$ \\
\hline & 2012 & $2.00 \mathrm{ab}$ & $2.09 \mathrm{a}$ & $1.75 \mathrm{bcd}$ & $1.80 \mathrm{bc}$ & $1.93 \mathrm{bc}$ & $1.87 \mathrm{~cd}$ & $1.82 \mathrm{bc}$ & $1.80 \mathrm{bc}$ \\
\hline & 2013 & $1.82 \mathrm{cde}$ & $2.11 \mathrm{a}$ & $1.82 \mathrm{cde}$ & $1.95 \mathrm{~b}$ & $1.85 \mathrm{bcd}$ & $1.96 \mathrm{~b}$ & $1.92 \mathrm{~b}$ & $1.88 \mathrm{bc}$ \\
\hline & 2011-2013 & $1.91 \mathrm{abc}$ & $2.06 \mathrm{a}$ & $1.77 \mathrm{bcdef}$ & $1.86 \mathrm{bcde}$ & $1.90 \mathrm{bcd}$ & $1.96 \mathrm{abcd}$ & $1.93 \mathrm{ab}$ & $1.90 \mathrm{abcd}$ \\
\hline
\end{tabular}

a, b, c... - statistically not significant differences between examined groups each year

Table 6. Mean oils content in different cultivars of dill (mean for 2011-2013)

\begin{tabular}{|c|c|c|c|c|c|c|c|c|c|}
\hline Cultivar & & 'Krezus' & 'Turkus' & 'Kozak' & 'Szmaragd' & 'Lukullus' & 'Herkules' & 'Ambrozja' & 'Moravan' \\
\hline Capability (\% f.m.) & & $0.30 \pm 0.08$ & $0.27 \pm 0.06$ & $0.26 \pm 0.06$ & $0.29 \pm 0.04$ & $0.30 \pm 0.07$ & $0.25 \pm 0.05$ & $0.24 \pm 0.05$ & $0.28 \pm 0.04$ \\
\hline Peak Name & $\mathrm{tR}(\min )$ & Area (\%) & Area (\%) & Area (\%) & Area (\%) & Area (\%) & Area (\%) & Area (\%) & Area (\%) \\
\hline (E)-2-Hexenal, 832 & 5.29 & $0.18 \pm 0.01$ & $0.10 \pm 0.12$ & $0.02 \pm 0.01$ & $0.19 \pm 0.08$ & $0.20 \pm 0.04$ & $0.02 \pm 0.01$ & $0.02 \pm 0.01$ & $0.02 \pm 0.01$ \\
\hline 3-Thujene, 932 & 7.03 & $0.27 \pm 0.01$ & $0.26 \pm 0.02$ & $0.38 \pm 0.06$ & $0.30 \pm 0.06$ & $0.24 \pm 0.03$ & $0.31 \pm 0.09$ & $0.29 \pm 0.06$ & $0.26 \pm 0.04$ \\
\hline a-Pinene, 936 & 7.34 & $1.26 \pm 0.04$ & $1.30 \pm 0.09$ & $1.44 \pm 0.27$ & $1.37 \pm 0.16$ & $1.67 \pm 0.34$ & $1.72 \pm 0.21$ & $1.31 \pm 0.21$ & $1.24 \pm 0.10$ \\
\hline Camphene, 950 & 7.85 & $0.02 \pm 0.01$ & $0.02 \pm 0.01$ & $0.02 \pm 0.01$ & $0.02 \pm 0.01$ & $0.02 \pm 0.01$ & $0.02 \pm 0.01$ & $0.02 \pm 0.01$ & $0.02 \pm 0.01$ \\
\hline Sabinene, 973 & 8.3 & $0.13 \pm 0.02$ & $0.12 \pm 0.01$ & $0.12 \pm 0.01$ & $0.12 \pm 0.05$ & $0.14 \pm 0.05$ & $0.14 \pm 0.04$ & $0.15 \pm 0.06$ & $0.12 \pm 0.03$ \\
\hline$\beta$-Pinene, 978 & 8.44 & $0.40 \pm 0.03$ & $0.28 \pm 0.15$ & $0.41 \pm 0.03$ & $0.34 \pm 0.12$ & $0.44 \pm 0.01$ & $0.47 \pm 0.03$ & $0.52 \pm 0.03$ & $0.19 \pm 0.21$ \\
\hline$\beta$-Myrcene, 987 & 8.58 & $0.35 \pm 0.08$ & $0.21 \pm 0.15$ & $0.54 \pm 0.10$ & $0.47 \pm 0.05$ & $0.49 \pm 0.17$ & $0.25 \pm 0.05$ & $0.33 \pm 0.04$ & $0.34 \pm 0.09$ \\
\hline$\alpha$-Phellandrene, 1002 & 9.22 & $63.99 \pm 0.34$ & $64.55 \pm 1.34$ & $61.99 \pm 3.84$ & $58.51 \pm 0.31$ & $62.83 \pm 1.30$ & $51.75 \pm 1.86$ & $50.78 \pm 0.62$ & $60.90 \pm 0.74$ \\
\hline p-Cymene, 1015 & 9.67 & $1.39 \pm 0.08$ & $1.71 \pm 0.46$ & $2.02 \pm 0.09$ & $2.29 \pm 0.37$ & $1.58 \pm 0.25$ & $1.95 \pm 2.66$ & $1.51 \pm 0.07$ & $1.33 \pm 0.04$ \\
\hline Limonene, 1025 & 9.81 & $2.41 \pm 0.09$ & $2.40 \pm 0.21$ & $2.37 \pm 0.29$ & $2.58 \pm 0.29$ & $2.66 \pm 0.18$ & $2.59 \pm 0.16$ & $2.65 \pm 0.36$ & $2.51 \pm 0.06$ \\
\hline$\beta$-Phellandrene, 1023 & 9.94 & $6.68 \pm 0.08$ & $6.81 \pm 0.87$ & $7.05 \pm 0.19$ & $5.34 \pm 0.26$ & $6.44 \pm 0.24$ & $6.91 \pm 0.21$ & $7.57 \pm 0.26$ & $5.48 \pm 0.32$ \\
\hline$\alpha$-Terpinene & 10.57 & $0.02 \pm 0.00$ & $0.03 \pm 0.02$ & $0.02 \pm 0.00$ & $0.03 \pm 0.02$ & $0.02 \pm 0.00$ & $0.02 \pm 0.01$ & $0.02 \pm 0.00$ & $0.02 \pm 0.00$ \\
\hline Terpinolen, 1082 & 11.39 & $0.51 \pm 0.07$ & $0.40 \pm 0.16$ & $0.24 \pm 0.04$ & $0.23 \pm 0.02$ & $0.20 \pm 0.03$ & $0.21 \pm 0.14$ & $0.17 \pm 0.02$ & $0.26 \pm 0.16$ \\
\hline Fenchone, 1069 & 11.66 & $0.05 \pm 0.04$ & $0.06 \pm 0.03$ & $0.02 \pm 0.01$ & $0.03 \pm 0.02$ & $0.03 \pm 0.02$ & $0.03 \pm 0.02$ & $0.03 \pm 0.03$ & $0.03 \pm 0.00$ \\
\hline Cis-2-menthen-1-ol & 12.58 & $0.02 \pm 0.01$ & $0.03 \pm 0.01$ & $0.02 \pm 0.00$ & $0.02 \pm 0.01$ & $0.02 \pm 0.01$ & $0.02 \pm 0.02$ & $0.05 \pm 0.04$ & $0.03 \pm 0.01$ \\
\hline Dill ether & 14.47 & $17.42 \pm 0.82$ & $14.87 \pm 0.23$ & $17.42 \pm 0.35$ & $21.64 \pm 1.43$ & $20.22 \pm 1.52$ & $24.81 \pm 1.88$ & $24.69 \pm 0.47$ & $17.33 \pm 0.56$ \\
\hline cis, trans-Dihydrocarvone & 14.75 & $0.09 \pm 0.04$ & $0.09 \pm 0.06$ & $0.12 \pm 0.07$ & $0.07 \pm 0.03$ & $0.08 \pm 0.04$ & $0.08 \pm 0.03$ & $0.10 \pm 0.05$ & $0.18 \pm 0.13$ \\
\hline Carvone & 15.36 & $0.05 \pm 0.04$ & $0.07 \pm 0.08$ & $0.10 \pm 0.04$ & $0.12 \pm 0.09$ & $0.21 \pm 0.04$ & $0.20 \pm 0.13$ & $0.20 \pm 0.16$ & $0.03 \pm 0.02$ \\
\hline Germacrene D & 22.65 & $0.30 \pm 0.17$ & $0.15 \pm 0.03$ & $0.44 \pm 0.04$ & $0.24 \pm 0.20$ & $0.43 \pm 0.02$ & $0.21 \pm 0.13$ & $0.18 \pm 0.11$ & $0.23 \pm 0.22$ \\
\hline Myristicin & 23.36 & $0.50 \pm 0.03$ & $0.51 \pm 0.08$ & $0.02 \pm 0.00$ & $0.09 \pm 0.12$ & $0.16 \pm 0.13$ & $0.37 \pm 0.61$ & $0.66 \pm 0.73$ & $0.97 \pm 1.30$ \\
\hline Apiol, 1649 & 25.7 & $2.58 \pm 0.27$ & $3.28 \pm 0.03$ & $2.04 \pm 0.00$ & $4.09 \pm 0.10$ & $1.05 \pm 0.04$ & $3.14 \pm 0.14$ & $2.57 \pm 0.49$ & $6.92 \pm 0.34$ \\
\hline Total & - & $98.62 \pm 1.13$ & $97.24 \pm 1.67$ & $96.81 \pm 3.90$ & $98.09 \pm 2.29$ & $99.13 \pm 0.81$ & $95.22 \pm 4.13$ & $93.82 \pm 0.80$ & $98.41 \pm 1.94$ \\
\hline
\end{tabular}




\section{Total and reducing sugars}

Plants synthesize sugars, mostly sucrose, in the reactions of photosynthesis that drive the growth and development, being the source of energy and carbon. Sugars affect the expression of certain genes involved in many essential processes, e.g. photosynthesis, cell cycle metabolism, defense mechanisms, glyoxylate metabolism, glycolysis, nitrogen metabolism, sucrose and starch metabolism (Jang and Sheen, 1997).

The content of sugars in cultivated plants is presented in Table 7. Our study has revealed that dill genotype does not have a significant impact on the content of those compounds. Nevertheless, the highest amount exhibits the

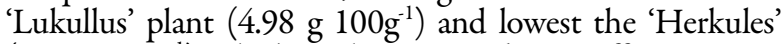

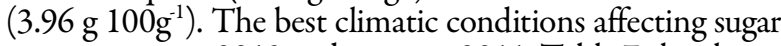
content were in 2013 and worst in 2011. Table 7 also shows

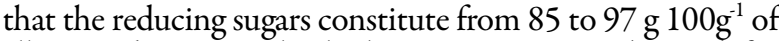
all assayed sugars. The highest amount was observed for 'Lukullus' and lowest for 'Herkules' and 'Szmaragd'. In the work of Karkleliene et al. (2014) the cultivars 'Moravan', 'Szmaragd', 'Common' and 'Mammoth' were similar in terms of total sugar content and amounted to 2.95, 3.07,

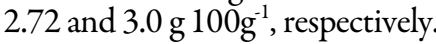

\section{$L$-ascrbic acid}

Ascorbic acid (AsA) is a naturally occurring compound in various vegetables and fruits (Magwaza et al., 2017). Numerous factors have an impact on the level of ascorbic acid in plant organs (e.g. preharvest cultural practices, genotype, climatic conditions, harvesting procedures, and postharvest management) (Magwaza et al., 2017) and is significantly different across species (Kka et al., 2017). AsA has basic functions in plant physiology (Liang et al., 2017), e.g. is a reducing agent in biochemical reaction, contributes to the antioxidant capacity of plant tissues, detoxifies reactive oxygen species and free radicals (Magwaza et al., 2017) and promotes resistance to senescence and environmental stresses (e.g. ozone, high light, salt and dehydration stress) (Liang et al., 2017). Its metabolism plays a significant role in photosynthesis, hormone biosynthesis (e.g. ethylene, jasmonic acid, salicylic acid, abscisic acid, gibberellic acid), growth regulation and senescence (Kka et al., 2017; Liang et al., 2017; Magwaza et al., 2017). Enhancement of ascorbic acid content in crops can improve their shelf-life (Magwaza et al., 2017). AsA is also important for human health. It protects against oxidative stress, participates in collagen synthesis, and promotes iron absorption and wound-healing. Moreover, due to the lack of human ability to synthesise ascorbic acid, it must be derived from diets (mostly from fruits and vegetables) (Liang et al., 2017). Because of these unique functions more attention has been paid to ascorbic acid content in food.

In most cases the content of L-ascobic acid (Table 8) in fresh garden dill was similar, neverthless the highest average amount was observed in 'Turkus' (171.91 mg. $100 \mathrm{~g}^{-1} \mathrm{f} . \mathrm{m}$.) followed by 'Ambrozja' (136.28 mg $100 \mathrm{~g}^{-1}$ f.m.) and 'Moravan' (124.88 mg $100 \mathrm{~g}^{-1} \mathrm{f} . \mathrm{m}$.), while the lowest in 'Szmaragd' (78.35 mg 100g-1 f.m.) and 'Lukullus' (88.80 mg $100 \mathrm{~g}^{-1} \mathrm{f} . \mathrm{m}$.). We have noticed that the ascorbic acid content decreased in subsequent years of cultivation. In most cases the content of AsA was much higher in comparison to the value presented by USDA ( $85.00 \mathrm{mg} 100 \mathrm{~g}^{-1} \mathrm{f} . \mathrm{m}$.). In the work of Naidu et al. (2016) the concentration of vitamin C in garden dill, determined by the visual titration method, amounted to $180.9 \mathrm{mg}$ in $100 \mathrm{~g}$ of fresh mass. Stan et al.

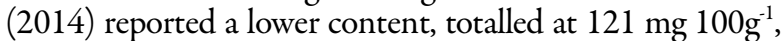
found by using HPLC.

Table 7. Total and reducing sugars content $\left(\mathrm{g} \cdot 100 \mathrm{~g}^{-1} \mathrm{f}\right.$.m.) in different cultivars of dill $(\mathrm{N}=4)$

\begin{tabular}{|c|c|c|c|c|c|c|c|c|}
\hline \multirow[b]{2}{*}{ Cultivar } & \multicolumn{4}{|c|}{ Total sugars } & \multicolumn{4}{|c|}{ Reducing sugars } \\
\hline & 2011 & 2012 & 2013 & Mean & 2011 & 2012 & 2013 & Mean \\
\hline 'Krezus' & $4.66 \mathrm{bc}$ & $4.73 \mathrm{bd}$ & $4.92 \mathrm{ac}$ & $4.77 \mathrm{ac}$ & $4.02 \mathrm{bcd}$ & $4.09 \mathrm{bc}$ & $4.28 \mathrm{ac}$ & $4.13 \mathrm{bcd}$ \\
\hline 'Turkus' & $4.70 \mathrm{abc}$ & $4.77 \mathrm{bc}$ & $4.96 \mathrm{ac}$ & $4.81 \mathrm{ac}$ & $3.98 \mathrm{bcd}$ & $4.05 b d$ & $4.24 \mathrm{a}$ & $4.09 \mathrm{bcd}$ \\
\hline 'Kozak' & $4.76 \mathrm{ab}$ & $4.83 \mathrm{ab}$ & $5.02 \mathrm{ab}$ & $4.87 \mathrm{ab}$ & $4.08 \mathrm{ac}$ & $4.15 \mathrm{ab}$ & $4.34 \mathrm{a}$ & $4.19 \mathrm{abc}$ \\
\hline 'Szmaragd' & $4.27 \mathrm{de}$ & $4.34 \mathrm{ef}$ & $4.53 \mathrm{df}$ & $4.38 \mathrm{df}$ & 3.86bcde & $3.93 \mathrm{bce}$ & $4.12 \mathrm{~cd}$ & $3.97 \mathrm{ce}$ \\
\hline 'Lukullus’ & $4.87 \mathrm{a}$ & $4.94 a$ & $5.13 \mathrm{a}$ & $4.98 \mathrm{a}$ & $4.33 \mathrm{a}$ & $4.40 \mathrm{a}$ & $4.59 \mathrm{a}$ & $4.44 a$ \\
\hline 'Herkules' & $3.85 f$ & $3.92 \mathrm{~g}$ & $4.11 \mathrm{~g}$ & $3.96 \mathrm{~g}$ & $3.75 \mathrm{ef}$ & $3.82 \mathrm{cdef}$ & 4.01cde & $3.86 \mathrm{def}$ \\
\hline 'Ambrozja’ & $4.38 \mathrm{~d}$ & $4.45 \mathrm{e}$ & $4.64 \mathrm{ce}$ & $4.49 \mathrm{ce}$ & $4.07 \mathrm{bc}$ & $4.14 \mathrm{bc}$ & $4.33 \mathrm{bc}$ & $4.18 b c$ \\
\hline 'Moravan' & $4.41 \mathrm{~d}$ & $4.48 \mathrm{e}$ & $4.67 \mathrm{~cd}$ & $4.52 \mathrm{~cd}$ & $4.15 \mathrm{ab}$ & $4.22 \mathrm{ab}$ & $4.41 \mathrm{ab}$ & $4.26 \mathrm{ab}$ \\
\hline
\end{tabular}

a, b, c... - statistically not significant differences between examined groups each year

Table 8. Antioxidant activity ( $\mu \mathrm{M}$ Trolox.g ${ }^{-1}$ f.m.) and L-ascorbic acid content $\left(\mathrm{mg} \cdot 100 \mathrm{~g}^{-1} \mathrm{f} . \mathrm{m}\right.$.) in different cultivars of dill $(\mathrm{N}=4)$

\begin{tabular}{|c|c|c|c|c|c|c|c|c|}
\hline \multirow[b]{2}{*}{ Cultivar } & \multicolumn{4}{|c|}{ L-ascorbic acid } & \multicolumn{4}{|c|}{ Antioxidant activity } \\
\hline & 2011 & 2012 & 2013 & Mean & 2011 & 2012 & 2013 & Mean \\
\hline 'Krezus' & $125.26 \mathrm{~d}$ & $122.84 \mathrm{c}$ & $119.48 \mathrm{c}$ & $122.52 \mathrm{c}$ & $6.16 \mathrm{~g}$ & $6.29 \mathrm{~g}$ & $6.37 \mathrm{a}$ & $6.27 \mathrm{e}$ \\
\hline 'Turkus' & $175.94 a$ & $171.80 \mathrm{a}$ & 168.01a & 171.91a & $12.66 \mathrm{a}$ & $12.79 \mathrm{a}$ & $11.21 \mathrm{ab}$ & $12.22 \mathrm{a}$ \\
\hline 'Kozak' & $123.28 \mathrm{e}$ & $122.33 c$ & $114.00 \mathrm{e}$ & $119.87 \mathrm{~cd}$ & $10.94 \mathrm{c}$ & $11.07 \mathrm{bc}$ & $9.94 \mathrm{ab}$ & $10.65 \mathrm{abc}$ \\
\hline 'Szmaragd' & $83.49 \mathrm{~h}$ & $80.61 \mathrm{~g}$ & $70.96 \mathrm{~h}$ & $78.35 f$ & $6.33 \mathrm{f}$ & $6.46 f$ & $8.02 \mathrm{abc}$ & $6.94 \mathrm{de}$ \\
\hline 'Lukullus' & $93.02 \mathrm{~g}$ & $89.30 \mathrm{f}$ & $84.09 \mathrm{~g}$ & $88.80 \mathrm{e}$ & $6.08 \mathrm{gh}$ & 6.21gh & $9.52 \mathrm{a}$ & $7.27 \mathrm{de}$ \\
\hline 'Herkules' & $122.78 \mathrm{ef}$ & $119.60 \mathrm{~cd}$ & $115.97 \mathrm{~d}$ & $119.45 \mathrm{~cd}$ & $10.63 \mathrm{~cd}$ & $10.76 \mathrm{~cd}$ & $12.29 \mathrm{ab}$ & $11.23 \mathrm{ab}$ \\
\hline 'Ambrozja' & $137.83 \mathrm{c}$ & $136.92 b$ & $134.08 \mathrm{~b}$ & $136.28 \mathrm{~b}$ & $11.62 b$ & $11.75 b$ & $11.94 \mathrm{ab}$ & $11.78 \mathrm{ab}$ \\
\hline 'Moravan' & $149.81 b$ & $113.97 \mathrm{cde}$ & $110.86 \mathrm{ef}$ & $124.88 \mathrm{c}$ & $8.42 \mathrm{e}$ & $8.55 \mathrm{e}$ & $9.53 \mathrm{ab}$ & $8.83 \mathrm{~cd}$ \\
\hline
\end{tabular}

a, b, c... - statistically not significant differences between examined groups each year 
790

\section{$D P P H$}

Nowadays, the increased interests in natural antioxidants, which are considered as important nutraceuticals on account of many health benefits, have been observed (Sharma and Bhat, 2009). To determine antioxidant activity many tests use accelerated oxidative conditions which provoke lipid oxidation, what makes these tests not always representative and for many antioxidants the risk of degradation is high. The risk of thermal degradation of tested molecules is eliminated in the diphenylpicrylhydrazyl (DPPH) free radical method because antioxidant efficiency is measured at ambient temperature, wherein the reactional mechanism between antioxidant and DPPH depends on the structural conformation of the antioxidant (Bondet et al., 1997).

From these findings it can be inferred that genotypes examined differ in antioxidant activity conducted with the DPPH method (Table 8). The greatest activity showed: 'Turkus' (12.22 $\mu \mathrm{M}$ Trolox g ${ }^{-1}$ f.w.), 'Ambrozja' (11.78 $\mu \mathrm{M}$ Trolox g ${ }^{-1}$ f.w.) and 'Herkules' (11.23 $\mu \mathrm{M}$ Trolox $\mathrm{g}^{-1}$ f.w.) while the lowest 'Krezus' (6.27 $\mu \mathrm{M}$ Trolox $\mathrm{g}^{-1}$ f.w.) and 'Szmaragd' (6.94 $\mu \mathrm{M}$ Trolox g ${ }^{-1}$ f.w.).

\section{Conclusions}

In the present study, eight genotypes of garden dill were tested. The conducted research proved that the genotype affects yield, content of bioactive compounds and antioxidant activity. The most favourable yielding featured cv. 'Krezus' and 'Szmaragd' and the least were 'Herkules'. The highest dry matter was obtained for cv. 'Krezus' and the lowest for cv. 'Ambrozja'. The lowest content of chlorophyll $a+b$ and carotenoids was observed in cv. 'Lukullus' and 'Szmaragd', respectively. The highest amount of these pigments was noted in cv. 'Moravan'. Nitrates were accumulated only to a small extent. The cultivar did not affect the content of $\mathrm{Mg}$ and $\mathrm{P}$. The highest content of $\mathrm{K}$ was observed in cv. 'Moravan', while the highest quantity of Ca was reported for cv. 'Turkus'. The lowest amount of these macroelements was noted for cv. 'Kozak'. The highest total content of oils was observed in 'Lukullus' and lowest in 'Ambrozja'. The sugar content was the highest in cv. 'Lukullus' and lowest in 'Herkules'. The highest quantity of L-ascorbic acid and antioxidant activity were observed for cv. 'Turkus' and lowest for cv. 'Szmaragd' and 'Krezus', respectively. Owing to the considerable differences in composition it is possible to choose a dill variety for its desired use. In conclusion, it is worthwhile to screen the commonly used plants for different biological activities because they might present a new alternative source for possible bioactive substances.

\section{References}

Berman J,Zorrilla-Lopez U, Farre G,Zhu CF, Sandmann G, Twyman RM, ... Christou P (2015). Nutritionally important carotenoids as consumer products. Phytochemistry Reviews 14(5):727-743.

Bondet V, Brand-Williams W, Berset C (1997). Kinetics and mechanisms of antioxidant activity using the DPPH free radical method. Lebensmittel-Wissenschaft \& Technologie 30(6):609-615.

Bowes KM, Zheljazkov VD, Caldwell CD, PincockJA, Roberts JC (2004).
Influence of seeding date and harvest stage on yields and essential oil composition of three cultivars of dill (Anethum graveolens L.) grown in NovaScotia. Canadian Journal of Plant Science 84(4):1155-1160.

Callan NW, Johnson DL, Westcott MP, Welty LE (2007). Herb and oil composition of dill (Anethum graveolens L.): Effects of crop maturity and plant density. Industrial Crops and Products 25(3):282-287.

Commission Regulation (2006). Commission Regulation (EC) No 1881/2006 of 19 December 2006: http://eur-lex.europa.eu/legalcontent/EN/TXT/PDF/?uri=CELEX:32006R1881\&from=EN.

Dec D, Wołejko E, Kubicka H, Matusiewicz M, Żylińska B (2008). Zawartość azotanów (III) i (V) w wybranych roślinach przyprawowych pochodzących $z$ handlu i ogródków przydomowych [The content of nitrates (III) and (V) in selected spice plants from trade and home gardens]. Ochrona Środowiska i Zasobów Naturalnych 35/36:255259.

El-Zaeddi H, Martinez-Tome J, Calin-Sanchez A, Burlo F, CarbonellBarrachina AA (2016). Volatile composition of essential oils from different aromatic herbs grown in Mediterranean regions of Spain. Foods 5(2):1-13.

El-Zaeddi H, Martinez-Tome J, Calin-Sanchez A, Burlo F, CarbonellBarrachina AA (2017). Irrigation dose and plant density affect the volatile composition and sensory quality of dill (Anethum graveolens L.). Journal of the Science of Food and Agriculture 97(2):427-433.

Farzadfar S, Zarinkamar F Hojati M (2017). Magnesium and manganese affect photosynthesis, essential oil composition and phenolic compounds of Tanacetum parthenium. Plant Physiology and Biochemistry 112:207-217.

Gammone MA, Riccioni G, D'Orazio N (2015). Marine carotenoids against oxidative stress: Effects on human health. Marine Drugs 13(10):6226-6246.

Garcez JJ, Barros F, Lucas AM, Xavier VB, Fianco AL, Cassel E, Vargas RMF (2017). Evaluation and mathematical modeling of processing variables for a supercritical fluid extraction of aromatic compounds from Anethum graveolens. Industrial Crops and Products 95:733-741.

Ghassemi-Golezani K, Zehtab-Salmasi S, Dastborhan S (2011). Changes in essential oil content of dill (Anethum graveolens) organs under salinity stress. Journal of Medicinal Plants Research 5(14):3142-3145.

Hajhashemi V, Abbasi N (2008). Hypolipidemic activity of Anethum graveolens in rats. Phytotherapy Research 2293):372-375.

Huang DL, Gong XM, Liu YG, Zeng GM, Lai C, Bashir H, ... Wan J (2017). Effects of calcium at toxic concentrations of cadmium in plants. Planta245(5):863-873.

Jang J-C, Sheen J (1994). Sugar sensing in higher plants. The Plant Cell 6(11):1665-1679.

Karkleliene R, Dambrauskiene E, Juskeviciene D, Radzevicius A, Rubinskiene M, Viskelis $P$ (2014). Productivity and nutritional value of dill and parsley. Horticultural Science 41(3):131-137.

Kawecka M, Dyduch J (2006). Ocena cech biometrycznych i potencjału plonotwórczego roślin kilku odmian kopru ogrodowego (Anethum graveolens L.) w uprawie polowej na zbiór pęczkowy. Ocena potencjału plonotwórczego [Evaluation of biometric features and yield potential of plants of several garden dill varieties (Anethum graveolens L.) in field cultivation for bunches. Evaluation of yield potential]. Acta Agrophysica 
8(3):611-617.

Kka N, Rookes J, Cahill D (2017). Quantitation of ascorbic acid in Arabidopsis thaliana reveals distinct differences between organs and growth phases. Plant Growth Regulation 81(2):283-292.

Liang D, Zhu TT, Ni ZY, Lin LJ, Tang Y, Wang ZH, ... Xia H (2017). Ascorbic acid metabolism during sweet cherry (Prunus avium) fruit development. PloSOne 12(2):1-16.

Magwaza LS, Mditshwa A, Tesfay SZ, Opara UL (2017). An overview of preharvest factors affecting vitamin $\mathrm{C}$ content of citrus fruit. Scientia Horticulturae 216:12-21.

Naidu MM, Vedashree M, Satapathy P, Khanum H, Ramsamy R, Hebbar $\mathrm{HU}$ (2016). Effect of drying methods on the quality characteristics of dill (Anethum graveolens) greens. Food Chemistry 192:849-856.

Nowosielski O (1988). Metody oznaczania potrzeb nawożenia roślin ogrodniczych [Methods for determining the needs of fertilizing horticultural plants]. PWRiL, Warszawa.

Olle M, Bender I (2010). The content of oils in umbelliferous crops and its formation. Agronomy Research 8(3):687-696.

PN-A-04019 (1998). Produkty spożywcze - Oznaczanie zawartości witaminy C [Food products-Determination of vitamin C content].

Rana VS, Blazquez MA (2014). Chemical composition of the essential oil of Anethum graveolens aerial parts. Journal of Essential Oil Bearing Plants 17(6):1219-1223.

Rădulescu V, Popescu ML, Ilieş DC (2010). Chemical composition of the volatile oil from different plant parts of Anethum graveolens L. (Umbelliferae) cultivated in Romania. Farmacia 58(5):594600.

Rumińska A, Suchorska K, Węglarz Z (1990). Rośliny lecznicze i specjalne [Medicinal and special plants].SGGW AR Warszawa.
Saini RK, NileSH, ParkSW (2015). Carotenoids from fruits and vegetables: Chemistry, analysis, occurrence, bioavailability and biological activities. Food Research International 76:735-750.

Sharma OP, Bhat TK (2009). DPPH antioxidant assay revisited. Food Chemistry 113(4):1202-1205.

Stan M, Soran ML, Marutoiu C (2014). Extraction and HPLC determination of the ascorbic acid content of three indigenous spice plants.Journal of Analytical Chemistry 69(10):998-1002.

Tamme T, Reinik M, Roasto M, Juhkam K, Tenno T, Kiis A (2006). Nitrates and nitrites in vegetables and vegetable-based products and their intakes by the Estonian population. Food Additives and Contaminants 23(4):355-361.

Telesiński A, Grzeszczuk M, Jadczak D, Wysocka G, Onyszko M (2013). Ocena zmian zawartości azotanów (V) w wybranych ziołach przyprawowych w zależności od sposobu ich utrwalenia i czasu przechowywania [Evaluation of changes in the content of nitrates $(V)$ in selected spice herbs depending on the method of their fixation and storage time]. Żywność. Nauka. Technologia.Jakość 5(90):168-176.

Weisany W, Raei Y, Pertot I (2015). Changes in the essential oil yield and composition of dill (Anethum graveolens L.) as response to arbuscular mycorrhiza colonization and cropping system. Industrial Crops and Products 77:295-306.

Yen GC, Chen HY (1995). Antioxidant activity of various tea extracts in relation to their antimutagenicity. Journal of Agricultural and Food Chemistry 43(1):27-32.

Zheljazkov VD, Craker LE, Xing BS (2006). Effects of Cd, Pb, and Cu on growth and essential oil contents in dill, peppermint, and basil. Environmental and Experimental Botany 58(1-3):9-16. 